\title{
Питання психології
}

УДК 159.947:355.01

DOI: $10.33099 / 2617-6858-21-63-5-20-26$

Вахоцька I. О. кандидат психологічних наук, доцент, доиент кафедри психології Уманського державного педагогічного університету імені Павла Тичини https://orcid.org/ 0000-0002-1611-4059

\section{ІННОВАЦІЙНИЙ ПОТЕНЦІАЛ КОАКТИВНОГО КОУЧІНГУ В ПРОЦЕСІ ПІДГОТОВКИ МАЙБУТНЬОГО ПСИХОЛОГА}

У статті розкривається інновачійний потенціал коактивного коучингу при підготовияі майбутнього психолога. Зазначається, щуо технологія коактивного коучингу представляє сукупність методів, засобів $i$ форм впливу на особистість майбутнього психолога, щчо забезпечують свободу його особистісно-професійного розвитку за допомогою взаємодії з іншими людьми.

Ключові слова: інновачійний потенціал технологія; особистісно-професійний розвиток.

Вступ. Швидкі зміни у суспільстві і жорстке конкурентне середовище усе сильніше викликають потребу в актуалізації різноманітних ресурсів адаптації i креативного потенціалу фахівців. Вони стають усе більш важливим ресурсом підвищення конкурентоспроможності організації, до якої вони належать чи у якій вони працюють. В.О. Толочек зазначає, що у психологічній практиці зі зміною установок роботи 3 клієнтом з'являється новий феномен, немислимий спочатку. Якщо раніше сферою i предметом діяльності психолога були реальні процеси, то тепер актуальною сферою діяльності психолога стають не стільки дії, скільки мети, наміри суб'єктів, які доцільно оформляти ще на стадії задуму [15].

Коучинг

розглядається як індивідуальне або групове тренування i професійна допомога, вид менеджменту, методика роботи зі здобувачем вищої освіти, спрямована на оптимізацію його внутрішніх ресурсів як суб'єкта у вирішенні проблем шляхом створення позитивної установки на успіх і відходу від проблемно-орієнтованого підходу у роботі з здобувачем вищої освіти. Він $\epsilon$ способом розвитку людей в організації 3 метою підвищення ефективності діяльності і реалізації їхнього потенціалу у повній мірі. Стосовно підготовки психолога коучинг-технологія - це спосіб фасилітації його особистісного розвитку.

коактивний коучинг; майбутній психолог;

Мета дослідження. Обгрунтувати i визначити інноваційний потенціал коактивного коучингу в процесі підготовки здобувача вищої освіти зі спеціальності «Психологія».

Теоретичне підгрунтя. Коучинг як технологія виникла на перетині психотерапії і консультування, тренінгу та фасилітації. У перекладі 3 англійської «Coaching» - наставляти, надихати, тренувати [17]. Виходячи 3 етимології слова, слід визначити, що вихідними моментами коучингу $\epsilon, 3$ одного боку, навичкові тренінги із закріплення конкретних моделей поведінки, з іншого особлива лінія наставництва i фасилитация, що забезпечує актуалізацію внутрішніх сил i можливостей майбутнього фахівця.

Витоки коучингу починаються у гуманістичному підході і психотерапії (А.Маслоу, К.Роджерс), роботах Д.Гоулмена у сфері емоційного інтелекту, сократівські методи діалогу, методики найбільш просунутих спортивних тренерів. На Заході парадигма коучингу як особливого стилю навчальної взаємодії розвинулася на основі рефлексії передових підходів у сфері наставництва, бізнесконсультування, психологічного консультування і психотерапії [18]. У найширшому розумінні коучинг $\epsilon$ способом розвитку людей в організації з метою підвищення ефективності діяльності і реалізації їхнього потенціалу у 


\section{Питання психології}

повній мірі. Його прийнято розглядати як розвивальну діяльність, а не як діяльність, спрямовану на виправлення недоліків у роботі $[2 ; 3 ; 4 ; 5 ; 6$ та ін.].

Методи дослідження. Теоретичний аналіз, синтез, узагальнення, порівняння.

Результати і обговорення. Виходячи iз узагальненої схеми коучингу він може розглядатись як метод (складова частини авторської програми, поряд із достатньо традиційними способами i прийомами), форма (з т. 3. особливостей організації групової та індивідуальної роботи), засіб реалізації поставлених завдань. Технологічність коучингу проявляється у досягненні стійких показників оптимізації розвитку фахівця, а також результатів роботи $[7 ; 8 ; 11 ; 13]$.

Коуч - це людина, яка використовує коучингові знання, вміння та здібності, не маючи владних повноважень над суб'єктом, з яким вона взаємодіє. Він має на меті створення для співробітника i спільно 3 ним атмосфери благополуччя, компетентності та усвідомленості як результатів коучингової взаємодії [16]. Особливе місце у теорії i практиці коучингу посідає установка на взаємодію. Зокрема, поява коактівного коучингу, де зроблено акцент на рівноактівній взаємодії наставника i співробітника дозволяє поглибити уявлення про механізми впливу коуча. Такою ілюстрацією $є$ технологія дидактичного комунікативного впливу, що визначає вихідні позиції суб'єкта та об'єкта впливу, механізми зміни їхніх ролей, а також способи організації взаємопов'язаної діяльності [18].

Коактивний коучинг базується на таких принципах:

- майбутній психолог з самого початку $\epsilon$ творчою, цілісною особистістю і володіє відповідними ресурсами;

- коактивний коучинг звертається до усього життя здобувача вищої освіти;

- постановка завдання виходить від здобувача вищої освіти;

- відносини між коучем (викладачем) i здобувачем вищої освіти $є$ цілеспрямованим альянсом.

Продуктом спільної роботи коуча i здобувача вищої освіти $\epsilon$ діяльність і навчання. Ці дві сили, поєднуючись разом, створюють зміну. Оскільки поняття діяльності, яка просуває здобувача вищої освіти уперед, $є$ центральним у коучингу, можна стверджувати, що однією 3 цілей коучингу $є$ каталізація діяльності майбутнього фахівця. Інший рушійною силою процесу зміни $є$ навчання. Навчання не $\epsilon$ просто побічним продуктом діяльності - це рівнопотужна i доповнююча сила, яка створює нові ресурси, розширює можливості і дає сили для змін. Коучинг - це індивідуальне тренування людини для досягнення значущих для неї цілей, підвищення ефективності планування, мобілізації внутрішнього потенціалу, розвитку необхідних здібностей і навичок, освоєння передових стратегій отримання результату. Ця методика призначена для розширення можливостей людей, які усвідомили потребу у змінах і що ставлять перед собою завдання професійного та особистісного зростання [14]. Вона може бути спрямована на реалізацію планів у самих різних сферах життя.

Клаттербак i Меггінсон виокремили такі рівні розвитку культури коучингу:

- зародковий: коучинг може мати місце, однак він $\epsilon$ випадковим i топменеджери не розглядаються як рольові моделі;

- тактичний: цінність створення культури коучингу визнається, але існує недостатньо глибоке розуміння його значення і необхідних елементів;

- стратегічний: люди готові до використання коучингу у широкому спектрі ситуацій; менеджери просять про коучингову підтримку, а топ-менеджери подають приклад, проводячи коучинг для своїх підлеглих;

- інтегрований: коучинг є і офіційною, i неформальною практикою. Співробітники отримують зворотний зв'язок у своїй діяльності і працюють над нею за допомогою коучингу [15].

Умови переходу до інтегративної коучингу: підтримка керівництва; систематичність і послідовність реалізації коучингу в освітньому процесі; відкритість процедур коучингу, у т. ч. 3 т. 3. внесення 


\section{Питання психології}

можливих ініціатив 3 боку тих, хто навчається; моніторинг результатів коучингу як безперервний контроль процесу і досягнутих ефектів в роботі.

Д.В. Ненашев зазначає, що метою спеціально організованого процесу взаємодії коуча і того, хто навчається, $\epsilon$ досягнення цілей останнього оптимальними (для нього) шляхами і в оптимальні терміни [11]. Основні відмінності коучингу від інших видів консультування перебувають саме у сфері «яким чином» (яким чином організовується цей процесс).

У цьому сенсі коучинг $є$ унікальним поєднанням переваг:

психотерапії: прийняття того, 3 ким взаємодіє коуч таким, як він є; створення безпечного простору для нього; відсутність внесення власних (коуча) розумінь, моделей, рецептів; допомоги суб'єкту в усвідомленні його картини світу, його цінностей;

тренерства: стимулювання активних змін; підтримка ініціативи, дії; допомога у створенні внутрішніх і зовнішніх стимулів; організація «виклику», ініціація спільної діяльності («давай разом»). Усе це робить коучинг особливим, надзвичайно продуктивним i дуже привабливим для тих, кому важливо управляти власним життям, реалізуючи власні таланти i здібності повністю. Т.Голві запропонував «формулу ефективності», яка показує, 3 чого ця сама ефективність складається: ефективність = потенціал-перешкода. Тобто для досягнення поставлених цілей необхідно максимізувати власний потенціал, усунути перешкоди (як внутрішні - страхи, припущення, стереотипи та ін., так і зовнішні несприятливе середовище, загрози зовнішнього оточення). На цьому i фокусується робота коуча.

У загальному вигляді етапи коучингу можна представити у такому вигляді. На першому етапі коуч визначає тактичні завдання і цілі; здобувач вищої освіти розставляє цільові орієнтири, пріоритети. На другому етапі в процесі дослідження поточної ситуації (визначення наявних ресурсів і обмежень) коуч намагається зрозуміти поточну ситуацію (проблему), задаючи питання i активно слухаючи; здобувач вищої освіти досліджує ситуацію i власне ставлення до неї спільно із коучем. На третьому етапі - визначення внутрішніх і зовнішніх перешкод на шляху до результату. Коуч намагається зрозуміти, що заважає здобувачеві вищої освіти у досягненні мети і допомогти йому в усвідомленні і дослідженні перешкод; здобувач вищої освіти досліджує власні внутрішні і зовнішні перешкоди. На четвертому етапі - вироблення та аналіз можливостей для подолання перешкод: коуч задає питання і використовує інші методи, що провокують здобувача вищої освіти до пошуку рішень і подолання обмежень; здобувач вищої освіти дослідує можливості для подолання перешкод. На п'ятому етапі - вибір конкретного варіанту дій і складання плану: коуч допомагає здобувачеві вищої освіти в аналізі можливостей; здобувач вищої освіти аналізує можливості, обирає конкретний варіант і складає план дій. На шостому етапі - остаточне сприйняття плану: коуч демонструє готовність допомогти здобувачеві вищої освіти у реалізації подальших дій; здобувач вищої освіти розуміє, що допомога коуча не завжди $є$ необхідною i доцільною. На сьомому етапі: коуч забезпечує необхідний супровід здобувача вищої освіти; перехід до дії як вирішення проблемної ситуації.

Коуч i здобувач вищої освіти домовляються про те, що конкретно повинно бути зроблено до наступної зустрічі (визначеного терміну). Поведінка коуча, його дії i способи впливу на здобувача багато у чому $\epsilon$ схожими 3 основними джерелами технології коучингу, такими як наставництво, терапія, консультування, тренінг. Фіксація відмінностей цих технологій від коучингу дозволяє, 3 одного боку, обгрунтувати значущість технології коучингу, з іншого врахувати слабкі і сильні аспекти його впливу на здобувача вищої освіти.

Таким чином, еволюція коучингу обумовлена специфікою та напрямами розвитку його системоутворюючих технологій: їхній розвиток зумовили 


\section{Питання психології}

установку коучингу на фасилітацію розвитку, відкритість об єкта коучингу до зовнішніх i внутрішніх впливів, безумовність пріоритету особистості об єкта коучингу в процесі взаємодії із коучем.

Взаємодію викладача і здобувача вищого освіти в процесі навчання можна розглянути 3 позицій управління i сучасних підходів до організації педагогічної взаємодії. Аспект управління поширюється на того, хто навчає, на того, хто навчається, та тих, хто опосередковує їхню взаємодію. Отже, викладач в процесі навчання здобувачів вищої освіти реалізує ті чи інші дидактичні впливи. Комплексність заявленого підходу полягає у сполученні трьох компонентів управлінського процесу (мета, засіб, результат) на основі позицій коуча i здобувача вищої освіти. Зв'язок їх обох на різних етапах коучингу забезпечується за допомогою функцій впливу.

Усе різноманіття підходів до управління самостійною навчальною діяльністю здобувачів вищої освіти можна типологізувати за трьома критеріями: ролі викладача, функцій впливу і ролі того, хто навчається. У педагогічній системі взаємодія суб'єктів освіти детермінована цілями, змістом і результатами освіти. Отже, визначення рівнів управління дозволяє окреслити позиції цілепокладання (вступна сесія коучингу), ціледосягнення (демонстрація нових можливостей) i целевиміру (заключна сесія коучингу).

В аспекті розгляду коучингу як методу, то він також має свою особливість. Коуч працює в одній площині - площині мети (цілепокладання, бачення, ціледосягнення, результат) і не вивчає переживання людини. Для майбутнього психолога це привабливо тим, що площина мети - це завжди площина досягнень, i мова коуча зазвичай $\epsilon$ позитивною та оптимістичною. Головне завдання коуча створити ту якість життя, яке буде забезпечувати суб'єкту задоволення.

Висновки. Переваги коактивного коучингу сконцентровано на технологіях досягнення результату з одного боку, і на можливостях суб'єкта, 3 іншого. Основні підходи до коактивного коучингу визначають оптимальне поєднання способів досягнення результату і способів актуалізації можливостей фахівця у роботі над собою. Технологія коактивного коучингу представляє сукупність методів, засобів i форм впливу на особистість майбутнього психолога, що забезпечують свободу його особистісно-професійного розвитку за допомогою взаємодії з іншими людьми. Технологічність коактивного коучингу полягає, з одного боку, у певній послідовності кроків і процедур роботи 3 фахівцем, 3 іншого - у варіативності i різноманітності застосованих методів i засобів для вирішення індивідуальних проблем майбутнього психолога. $\mathrm{y}$ тактичному аспекті технології коактивного коучингу варіюються від навчальних сесій та семінарів до автотренінгів і консультацій: коучинг, акумулюючи досягнення технологій психотерапії, тренінгу, наставництва, фасилітації дозволяє забезпечити ненасильницьке прийняття філософії саморозвитку на основі зміни установок майбутнього психолога - від проблемно-центрованої взаємодії до роботи з його можливостями і ресурсами.

\section{Список використаних джерел}

1. Болтівець C.I. Українська психологічна термінологія: словник-довідник / укл. С.I. Болтівць, Н.В. Слободяник, М.-Л.А. Чепа, Н.В. Чепелєва. К.: ДП «Інформаційно-аналітичне агентство», 2010. $302 \mathrm{c.}$

2. Гичко Ю.В. Коуч-технології як засіб формування емоційної компетеності майбутніх психологів. Вісник національного університету оборони Украйни. 2021. Вип. 1 (59). С. $72-78$.

3. Гурієвська В. Коучинг як прикладна технологія державного управління. Вісник Наu. акад. держ. упр. при Президентові Украӥни. 2011. Вип. 1. С. 32-39. URL: http://nbuv.gov.ua/jpdf/Vnadu_2011_1_6.pdf 


\section{Питання психології}

4. Єфімова О.М., Жицька С.А. Коучинг як складова особистісно-орієнтованого навчання у професійній підготовці студентів вищих навчальних закладів. Журнал «Науковий огляд». №4(36), 2017. С. 1-10.

5. Зеленко Н.В., Ковалева Ю.Ю. Коучинг как инновационная технология управления индивидуально-личностным развитием обучающихся. Технолого-экономическое образование. 2018. №9. С. 23-27.

6. Козлова Е.Б. Изучение возможностей применения коуч-технологий в образовании как средство саморазвития личности магистрантов психолого-педагогического направления подготовки. Психология. Историко-критические обзоры и современные исследования. 2019. Т.8. №1A. C. 304-312.

7. Кострова Ю.Б., Шибаршина О.Ю. Коучинг как инновационная образовательная технология. Образовательные ресурсы и технологии. 2019. №2(27). С.27-32.

8. Кулемина Е.В. Коучинг - эффективная технология психолого-педагогического сопровождения учащихся. Психология учебной и профессиональной деятельности. Новосибирск: Общество с ограниченной ответственностью «Академиздат», 2018. С. 34-38.

9. Лев Н.Ю., Бала Р.Д. Моделі коучингу: характеристика та особливості застосування. Вісник Наи. ун-ту «Львів. Політехніка»: зб. наук. пр. 2012. № 727. С. 76-81.

10. Мария Илиф-Вуд. Как превратить сознательное в бессознательное в работе коуча. М.: Претекст. 2016. 252 с.

11. Ненашев Д.В. Коучинг как эффективная технология формирования эмоциональной компетентности будущих менеджеров: автореф. дис. канд. экон. наук. М., 2009. 24 с.

12. Панкратова И.А. Формирование эмоциональной компетентности студентов по технологии коучинга. Профессиональное образование в России и за рубежом 3 (27) 2017. С. $103-$ 110.

13. Парслоу Э., Рей М. Коучинг в обучении: практические методы и техники. СПб.: Питер, 2013. $204 \mathrm{c}$.

14. Сідак В.С., Сафін О.Д. Психолого-акмеологічні основи професійного та особистісного самовдосконалення співробітників правоохоронних органів України. Монографія. К.: НА СБУ, 2004. $124 \mathrm{c}$.

15. Толочек В.А., Тимашкова Н.А., Денисова В.Г. Профессиональное становление субъектов педагогической деятельности: позитивные и негативные изменения. Вестник Московского университета. Серия 14: Психология. 2014. №1. С. 16-32.

16. Clutterbuck, D and Megginson, D (2010) Coach maturity: An emerging concept. International Journal of Mentoring and Coaching, 8(1).

17. Jonathan Passmore, Tracy Sinclair. Becoming a Coach. Springer, Cham. 2020. 297 p.

18. Oxford Dictionary of English (3 ed.) Edited by Angus Stevenson. Publisher: Oxford University Press. Print Publication Date: 2010.

19. Overduin C. Pedagogisch coach, iets voor jou?. Kinderopvang 28, 8-9 (2018). https://doi.org/10.1007/s41189-018-0067-8.

20. Wendy-Ann Smith, Ilona Boniwell, Suzy Green. Positive Psychology Coaching in the Workplace. Springer, Cham, 2021. 587 p.

\section{References}

1. Boltivec' C.I. (2010) Ukrai'nc'ka pcyxologichna terminologija: clovnyk-dovidnyk [Ukrainian Psychological Terminology: Glossary] / ukl. C.I. Boltivc', N.V. Clobodjanyk, M.-L.A. Chepa, N.V. Chepeljeva. K.: DP «Informacijno-analitychne agentctvo». 302 c. (in Ukranian)

2. Gychko Ju.V. (2021) Kouch-tehnologii' jak zasib formuvannja emocijnoi' kompetenosti majbutnih psyhologiv [Coach technology as a means of forming the emotional competence of future psychologists]. Visnyk nacional'nogo universytetu oborony Ukrai'ny. Vyp. 1 (59). S. 72-78. (in Ukranian)

3. Gurijevc'ka V. (2011) Kouchyng jak prykladna texnologija derzhavnogo upravlinnja [Coaching as an applied technology of public administration]. Vicnyk Nac. akad. derzh. upr. pry Prezydentovi Ukrai'ny. Vyp. 1. C. 32-39. URL: http://nbuv.gov.ua/jpdf/Vnadu_2011_1_6.pdf (in Ukranian)

4. Jefimova O.M., Zhyc'ka C.A. (2017) Kouchyng jak ckladova ocobycticno-orijentovanogo navchannja u profecijnij pidgotovci ctudentiv vyshhyx navchal'nyx zakladiv [Coaching as a component of personal-oriented training in vocational training of students of higher educational institutions]. Zhurnal «Naukovyj ogljad». №4(36), 2017. C. 1-10. (in Ukranian) 


\section{Питання психології}

5. Zelenko N.V., Kovaleva Ju.Ju. (2018) Kouchyng kak innovacyonnaja texnologyja upravlenyja yndyvydual'no-lychnoctnim razvytyem obuchajushhyxcja [Coaching as an innovative technology for managing individual and personal development of students]. Texnologo-ekonomycheckoe obrazovanye. 2018. №9. C. 23-27. (in Russian)

6. Kozlova E.B. (2019) Yzuchenye vozmozhnoctej prymenenyja kouch-texnologyj v obrazovanyy kak credctvo camorazvytyja lychnocty magyctrantov pcyxologo-pedagogycheckogo napravlenyja podgotovky [The study of the possibilities of using coaching technology in education as a means of personal development of magicians of psycho-pedagogical education]. Pcyxologyja. Yctorykokrytycheckye obzorы y covremennыe yccledovanyja. T.8. №1A. C. 304-312. (in Russian)

7. Koctrova Ju.B., Shybarshyna O.Ju. (2019) Kouchyng kak ynnovacyonnaja obrazovatel'naja texnologyja [Coaching as an innovative educational technology]. Obrazovatel'nie recurci y texnologyy. №2(27). C.27-32. (in Russian)

8. Kulemyna E.V. (2018) Kouchyng - effektyvnaja texnologyja pcyxologo-pedagogycheckogo coprovozhdenyja uchashhyxcja [Coaching is an effective technology of psycho-pedagogical support of students]. Pcyxologyja uchebnoj y profeccyonal'noj dejatel'nocty. Novocybyrck: Obshhectvo c ogranychennoj otvetctvennoct'ju «Akademyzdat», 2018. C. 34-38. (in Russian)

9. Lev N.Ju., Bala R.D. (2012) Modeli kouchyngu: xarakteryctyka ta ocoblyvocti zactocuvannja [Coaching models: characteristics and features of using]. Vicnyk Nac. un-tu «L'viv. Politexnika»: zb. nauk. pr. №727. C. 76-81. (in Ukranian)

10. Maryja Ylyf-Vud. (2016) Kak prevratyt' soznatel'noe v bessoznatel'noe v rabote koucha [How to turn the conscious into the unconscious in the work of a coach]. M.: Pretekst. 252 s. (in Russian)

11. Nenashev D.V. (2009) Kouchyng kak эffektyvnaja texnologyja formyrovanyja эmocyonal'noj kompetentnocty budushhyx menedzherov [Coaching as an effective technology for the formation of the emotive competence of future managers]: avtoref. dyc. kand. ekon. nauk. M. 24 c. (in Russian)

12. Pankratova Y.A. (2017) Formyrovanye эmocyonal'noj kompetentnosty studentov po tehnologyy kouchynga [Formation of emotional competence of students using coaching technology]. Professyonal'noe obrazovanye v Rossyy y za rubezhom 3(27). S. 103-110. (in Russian)

13. Parclou Э., Rej M. (2013) Kouchyng v obuchenyy: praktycheckye metodi y texnyky [Coaching in training: practical methods and techniques]. CPb.: Pyter. 204 c. (in Russian)

14. Sidak V.S., Safin O.D. (2004) Psyhologo-akmeologichni osnovy profesijnogo ta osobystisnogo samovdoskonalennja spivrobitnykiv pravoohoronnyh organiv Ukrai'ny [Psychological and acmeological bases of professional and personal self-improvement of law enforcement officers of Ukraine]. Monografija. K.: NA SBU. 124 s. (in Ukranian)

15. Tolochek V.A., Timashkova N.A., Denisova V.G. (2014) Professional'noe stanovlenie sub\#ektov pedagogicheskoj dejatel'nosti: pozitivnye i negativnye izmenenija [Professional formation of subjects of pedagogical activity: positive and negative changes]. Vestnik Moskovskogo universiteta. Serija 14: Psihologija. №1. S. 16-32. (in Russian)

16. Clutterbuck, D and Megginson, D (2010) Coach maturity: An emerging concept. International Journal of Mentoring and Coaching, 8(1).

17. Jonathan Passmore, Tracy Sinclair. (2020) Becoming a Coach. Springer, Cham. 297 p.

18. Oxford Dictionary of English (3 ed.) Edited by Angus Stevenson. Publisher: Oxford University Press. Print Publication Date: 2010.

19. Overduin C. (2018) Pedagogisch coach, iets voor jou?. Kinderopvang 28, 8-9. https://doi.org/10.1007/s41189-018-0067-8.

20. Wendy-Ann Smith, Ilona Boniwell, Suzy Green. (2021) Positive Psychology Coaching in the Workplace. Springer, Cham. 587 p.

\section{Резюме}

Вахоцкая И. А. кандидат психологических наук, доцент, доиент кафедры психологии Уманского государственного

ИННОВАЦИОННЫЙ ПОТЕНЦИАЛ КОАКТИВНОГО КОУЧИНГА В ПРОЩЕССЕ ПОДГОТОВКИ БУДУЩЕГО ПСИХОЛОГА

В статье раскрывается инновационный потенциал коактивного коучинга при подготовке будущего психолога. Отмечается, что технология коактивного коучинга представляет совокупность методов, средств и форм воздействия на личность будущего психолога, 


\section{Питання психології}

обеспечивающие свободу его личностно-профессионального развития посредством взаимодействия с другими людьми.

Ключевые слова: инновационный потенциал; коактивний коучинг; будущий психолог; технология; личностно-профессиональное развитие.

\section{Summary}

Vahotskaya I. O. Uman state pedagogical

\section{THE INNOVATIVE POTENTIAL OF COACTIVE COACHING}

\section{IN THE PREPARATION OF A FUTURE PSYCHOLOGIST}

Introduction. Rapid changes in society and a tough competitive environment increasingly call for the need to update the various resources of adaptation and creative potential of professionals. They are becoming an increasingly important resource for increasing the competitiveness of the organization to which they belong or in which they work. It is possible to update this resource by unlocking the innovative potential of coactive coaching.

Purpose. To substantiate and determine the innovative potential of coactive coaching in the process of preparing a graduate in the specialty "Psychology".

Methods. Theoretical analysis, synthesis, comparison, generalization.

Originality. The interaction of teacher and graduate in the learning process can be considered from the standpoint of management and modern approaches to the organization of pedagogical interaction. The governance aspect extends to the learner, to the learner, and to those who mediate their interaction. Thus, the teacher in the process of teaching higher education students implements certain didactic influences. The complexity of the stated approach is to combine the three components of the management process (goal, means, result) based on the positions of the coach and the graduate. The connection of both of them at different stages of coaching is provided by the functions of influence. Coactive coaching is based on the following principles: the future psychologist from the very beginning is a creative, holistic personality and has the appropriate resources; the relationship between a coach (teacher) and a higher education seeker is a purposeful alliance.

Conclusion. The advantages of coactive coaching are focused on the technologies of achieving results on the one hand, and on the capabilities of the subject, on the other. The main approaches to coactive coaching determine the optimal combination of ways to achieve results and ways to update the capabilities of the specialist in working on themselves. The technology of coactive coaching is a set of methods, tools and forms of influence on the personality of the future psychologist, ensuring the freedom of his personal and professional development through interaction with other people.

Procedures for working with a specialist, on the other - in the variability and variety of methods and tools used to solve individual problems of the future psychologist. In the tactical aspect, the technologies of coactive coaching vary from training sessions and seminars to self-training and counseling: coaching, accumulating the achievements of psychotherapy, training, mentoring, facilitation allows to ensure nonviolent acceptance of the philosophy of self-development. its capabilities and resources.

Key words: innovative potential; coactive coaching; future psychologist; technology; personal and professional development.

Recelved/Поступила: 11.10.21. 